\title{
Genome sequence of the clover-nodulating Rhizobium leguminosarum bv. trifolii strain SRDI943
}

\author{
Wayne Reeve ${ }^{* 1}$, Elizabeth Drew ${ }^{2}$, Ross Ballard², Vanessa Melino', Rui Tian', Sofie De \\ Meyer ${ }^{1}$, Lambert Brau ${ }^{3}$, Mohamed Ninawi ${ }^{1}$, Hajnalka Daligault ${ }^{4,5}$, Karen Davenport ${ }^{4}$, Tracy \\ Erkkila $^{4}$, Lynne Goodwin ${ }^{5}$, Wei Gu ${ }^{4}$, Christine Munk ${ }^{4}$, Hazuki Teshima ${ }^{4}$, Yan Xu ${ }^{4}$, Patrick \\ Chain $^{4}$ and Nikos Kyrpides \\ ${ }^{1}$ Centre for Rhizobium Studies, Murdoch University, Western Australia, Australia \\ ${ }^{2}$ South Australian Research and Development Institute, Urrbrae, South Australia, Australia \\ ${ }^{3}$ School of Life and Environmental Sciences, Faculty of Science \& Technology, Deakin \\ University, Melbourne, Victoria, Australia \\ ${ }^{4}$ Los Alamos National Laboratory, Bioscience Division, Los Alamos, New Mexico, USA \\ ${ }^{5}$ DOE Joint Genome Institute, Walnut Creek, California, USA
}

*Correspondence: Wayne Reeve (W.Reeve@murdoch.edu.au)

Keywords: root-nodule bacteria, nitrog en fixation, rhizobia, Alphaproteobacteria

\begin{abstract}
Rhizobium leguminosarum bv. trifolii SRDI943 (strain syn. V2-2) is an aerobic, motile, Gramnegative, non-spore-forming rod that was isolated from a root nodule of Trifolium michelianum Savi cv. Paradana that had been grown in soil collected from a mixed pasture in Victoria, Australia. This isolate was found to have a broad clover host range but was sub-optimal for nitrogen fixation with T. subterraneum (fixing 20-54\% of reference inoculant strain WSM1325) and was found to be totally ineffective with the clover species T. polymorphum and T. pratense. Here we describe the features of $R$. leguminosarum bv. trifolii strain SRDI943, together with genome sequence information and annotation. The 7,412,387 bp high-quality-draft genome is arranged into 5 scaffolds of 5 contigs, contains 7,317 protein-coding genes and 89 RNA-only encoding genes, and is one of 100 rhizobial genomes sequenced as part of the DOE Joint Genome Institute $2010 \mathrm{Ge-}$ nomic Encyclopedia for Bacteria and Archaea-Root Nodule Bacteria (GEBA-RNB) project.
\end{abstract}

\section{Introduction}

The availability of usable nitrogen $(\mathrm{N})$ is vital for productivity in agricultural systems that are $\mathrm{N}$ deficient [1]. It can be supplied exogenously in the form of industrially synthesized fertilizers. However, this practice is expensive since fertilizer manufacture depends on the availability of fossil fuels that are burnt to support the industrial process of chemical $\mathrm{N}$-fixation. A far more economical practice is to supply plant-available $\mathrm{N}$ to farming systems by exploiting the process of biological $\mathrm{N}$-fixation that occurs in a symbiotic relationship between legumes and their rhizobial microsymbionts [2]. In this specific association, atmospheric inert dinitrogen gas is converted into bioavailable $\mathrm{N}$ to support legume growth.

Pasture legumes, including the clovers that comprise the Trifolium genus, are major contributors of biologically fixed nitrogen $\left(\mathrm{N}_{2}\right)$ to mixed farm- ing systems throughout the world [3,4]. In Australia, soils with a history of growing Trifolium spp. have developed large and symbiotically diverse populations of Rhizobium leguminosarum bv. trifolii ( $R$. l. trifolii) that are able to infect and nodulate a range of clover species. The $\mathrm{N}_{2}$-fixation capacity of the symbioses established by different combinations of clover hosts (Trifolium spp.) and strains of $R$. l. trifolii can vary from 10 to $130 \%$ when compared to an effective host-strain combination [5-8].

R. l. trifolii strain SRDI943 (syn. V2-2 [9]) was isolated from a nodule recovered from the roots of the annual clover Trifolium michelianum Savi cv. Paradana that had been inoculated with soil collected from under a mixed pasture at Walpeup, Victoria, Australia and grown in N deficient media for four weeks after inoculation, in the greenhouse 
[10]. SRDI943 forms an effective symbiosis with $T$. purpureum but sub-optimal $\mathrm{N}_{2}$-fixation symbiosis with T. subterraneum cv. Campeda and Clare $(\sim 24$ and 54\% respectively of that with strain WSM1325 $[9,11])$. Here we present a preliminary description of the general features for $R$. l. trifolii strain SRDI943 together with its genome sequence and annotation.

\section{Classification and general features}

R. l. trifolii strain SRDI943 is a motile, Gramnegative rod (Figure 1 Left and Center) in the order Rhizobiales of the class Alphaproteobacteria. It is fast growing, forming colonies within 3-4 days when grown on half strength Lupin Agar ( $1 / 2 \mathrm{LA})$ [12] at $28^{\circ} \mathrm{C}$. Colonies on $1 / 2 \mathrm{LA}$ are white-opaque, slightly domed and moderately mucoid with smooth margins (Figure 1 Right).

Minimum information about the Genome Sequence (MIGS) is provided in Table 1. Figure 2 shows the phylogenetic relationship of $R$. l. trifolii strain SRDI943 to root nodule bacteria in the order Rhizobiales in a 16S rRNA sequence based tree. This strain clusters closest to $R$. l. trifolii T24 and Rhizobium leguminosarum bv. phaseoli RRE6 with $100 \%$ and $99.8 \%$ sequence identity, respectively.

\section{Symbiotaxonomy}

R. l. trifolii SRDI943 forms nodules on $\left(\mathrm{Nod}^{+}\right)$and fixes $\mathrm{N}_{2}\left(\mathrm{Fix}^{+}\right)$with a range of annual and perenni- al clover species of Mediterranean origin (Table 2). SRDI943 forms white, ineffective (Fix-) nodules with the perennial clover $T$. pratense and $T$. polymorphum.

\section{Genome sequencing and annotation information \\ Genome project history}

This organism was selected for sequencing on the basis of its environmental and agricultural relevance to issues in global carbon cycling, alternative energy production, and biogeochemical importance, and is part of the Community Sequencing Program at the U.S. Department of Energy, Joint Genome Institute (JGI) for projects of relevance to agency missions. The genome sequence is deposited in the Genomes OnLine Database (GOLD) [33] and an improved-high-quality-draft genome sequence in IMG/GEBA. Sequencing, finishing and annotation were performed by the JGI. A summary of the project information is shown in Table 3.

\section{Growth conditions and DNA isolation}

R. l. trifolii strain SRDI943 was cultured to mid logarithmic phase in $60 \mathrm{ml}$ of TY rich media [34] on a gyratory shaker at $28^{\circ} \mathrm{C}$. DNA was isolated from the cells using a CTAB (Cetyl trimethyl ammonium bromide) bacterial genomic DNA isolation method [35].
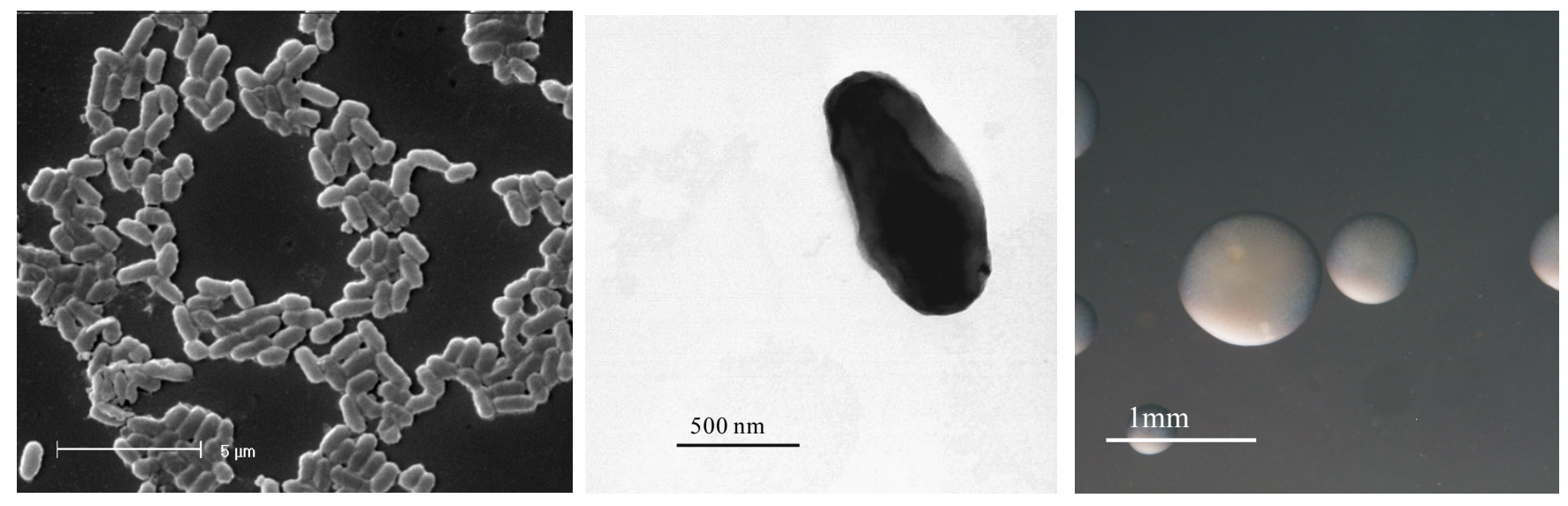

Figure 1. Images of Rhizobium le guminosarum bv. trifolii strain SRDI943 using scanning (Left) and transmission (Center) electron microscopy as well as light microscopy to show the colony morphology on solid media (Right). 
Table 1. Classification and general features of Rhizobium leguminosarum bv. trifolii SRDI943 according to the MIGS recommendations [13]

\begin{tabular}{|c|c|c|c|}
\hline MIGS ID & Property & Term & Evidence code \\
\hline & \multirow{7}{*}{ Current classification } & Domain Bacteria & TAS [14] \\
\hline & & Phylum Proteobacteria & TAS [15] \\
\hline & & Class Alphaproteobacteria & TAS $[16,17]$ \\
\hline & & Order Rhizobiales & TAS $[17,18]$ \\
\hline & & Family Rhizobiaceae & TAS [19-21] \\
\hline & & Genus Rhizobium & TAS [21-26] \\
\hline & & Species Rhizobium leguminosarum bv. trifolii & TAS $[21,23,27,28]$ \\
\hline & Gram stain & Negative & IDA \\
\hline & Cell shape & Rod & IDA \\
\hline & Motility & Motile & IDA \\
\hline & Sporulation & Non-sporulating & NAS \\
\hline & Temperature range & Mesophile & NAS \\
\hline & Optimum temperature & $28^{\circ} \mathrm{C}$ & NAS \\
\hline & Salinity & Non-halophile & NAS \\
\hline \multirow[t]{3}{*}{ MIGS-22 } & Oxygen requirement & Aerobic & TAS [11] \\
\hline & Carbon source & Varied & NAS \\
\hline & Energy source & Chemoorg anotroph & NAS \\
\hline MIGS-6 & Habitat & Soil, root nodule, on host & TAS [9] \\
\hline MIGS-15 & Biotic relationship & Free living, symbiotic & TAS [9] \\
\hline \multirow[t]{3}{*}{ MIGS-14 } & Pathog enicity & Non-pathogenic & NAS \\
\hline & Biosafety level & 1 & TAS [29] \\
\hline & Isolation & Root nodule & TAS [9] \\
\hline MIGS-4 & Geographic location & Victoria, Australia & TAS [9] \\
\hline MIGS-5 & Soil collection date & Dec, 1998 & IDA \\
\hline MIGS-4. 1 & Long itude & 142.0262 & \\
\hline MIGS-4.2 & Latitude & -35.13531 & IDA \\
\hline MIGS-4.3 & Depth & $0-10 \mathrm{~cm}$ & \\
\hline MIGS-4.4 & Altitude & Not recorded & \\
\hline
\end{tabular}

Evidence codes - IDA: Inferred from Direct Assay; TAS: Traceable Author Statement (i.e., a direct report exists in the literature); NAS: Non-traceable Author Statement (i.e., not directly observed for the living, isolated sample, but based on a generally accepted property for the species, or anecdotal evidence). These evidence codes are from the Gene Ontology project [30]. 


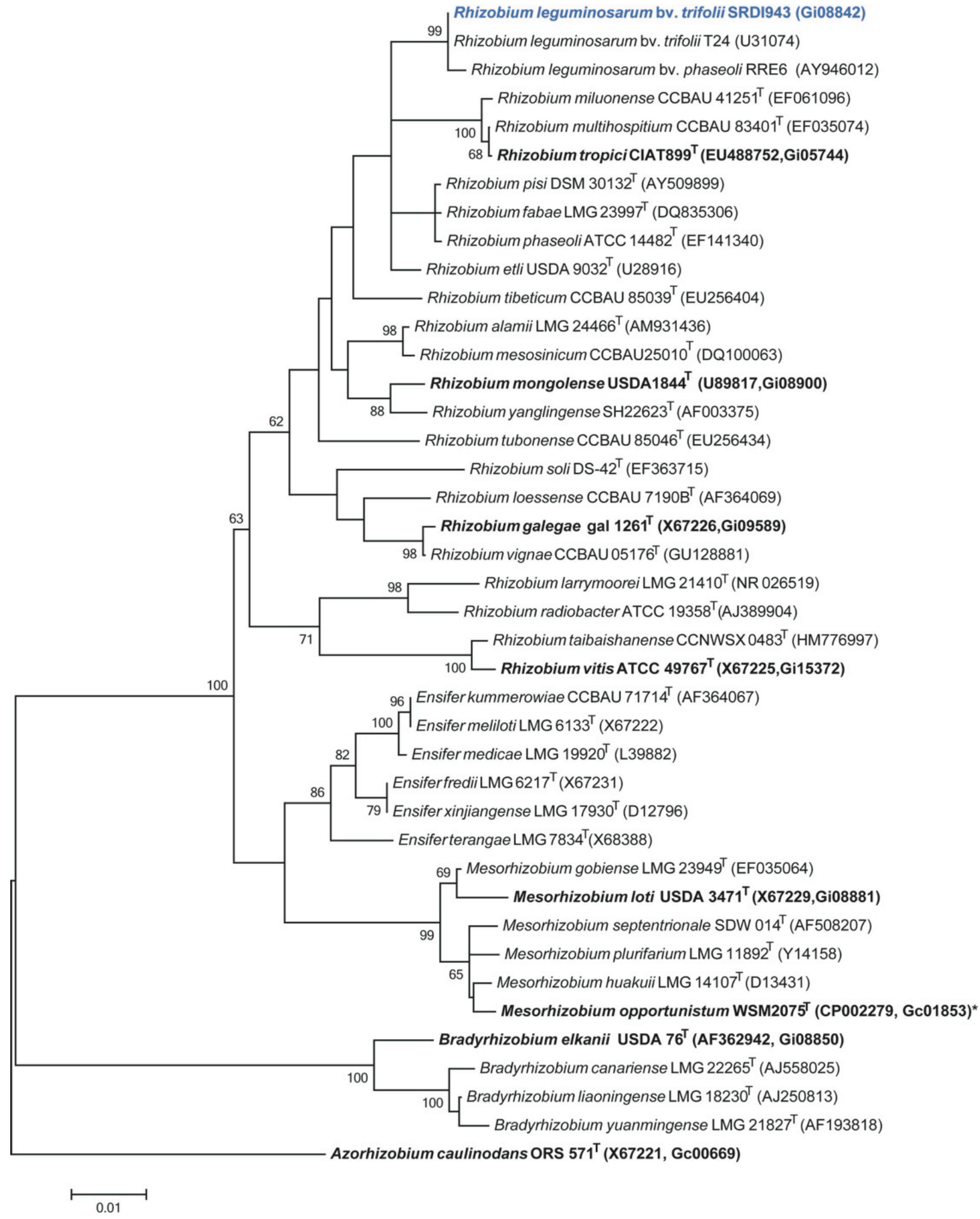

Figure 2. Phylogenetic tree showing the relationship of Rhizobium leguminosarum bv. trifolii SRDI943 (shown in blue print) with some of the root nodule bacteria in the order Rhizobiales based on aligned sequences of the $16 \mathrm{~S}$ rRNA gene (1,307 bp internal region). All sites were informative and there were no gapcontaining sites. Phylogenetic analyses were performed using MEGA, version 5.05 [31]. The tree was built using the maximum likelihood method with the General Time Reversible model. Bootstrap analysis [32] with 500 replicates was performed to assess the support of the clusters. Type strains are indicated with a superscript T. Strains with a genome sequencing project registered in GOLD [33] are in bold print and the GOLD ID is mentioned after the accession number. Published genomes are indicated with an asterisk. 
Table 2. Compatibility of SRDI943 with eleven Trifolium genotypes for nodulation (Nod) and $\mathrm{N}_{2}$-Fixation (Fix)

\begin{tabular}{|c|c|c|c|c|c|c|}
\hline Species Name & Cultivar & Common Name & Growth Type & Nod & Fix & Reference \\
\hline T. glanduliferum Boiss. & Prima & Gland & Annual & + & + & \\
\hline T. michelianum Savi. & Bolta & Balansa & Annual & + & + & \\
\hline T. purpureum Loisel & Paratta & Purple & Annual & + & + & {$[11]$} \\
\hline T. resupinatum $\mathrm{L}$. & Kyambro & Persian & Annual & + & + & \\
\hline T. subterraneum L. & Campeda & Sub. clover & Annual & + & + & {$[9,11]$} \\
\hline T. subterraneum L. & Clare & Sub. clover & Annual & + & + & {$[9,11]$} \\
\hline T. vesiculos um Savi. & Arrotas & Arrowleaf & Annual & + & + & \\
\hline T. fragiferum $\mathrm{L}$. & Palestine & Strawberry & Perennial & + & + & \\
\hline T. polymorphum Poir & Acc. \#087102 & Polymorphous & Perennial & $+(w)$ & - & {$[11]$} \\
\hline T. pratense L. & - & Red & Perennial & $+(\mathrm{w})$ & - & \\
\hline T. repens $\mathrm{L}$. & Haifa & White & Perennial & + & + & \\
\hline
\end{tabular}

(w) indicates nodules present were white.

Table 3. Genome sequencing project information for Rhizobium leguminosarum bv. trifolii strain SRDI943.

\begin{tabular}{lll}
\hline MIGS ID & Property & Term \\
\hline MIGS-31 & Finishing quality & Improved hig h-quality draft \\
MIGS-28 & Libraries used & $2 \times$ Illumina libraries; Std short PE \& CLIP Iong PE \\
MIGS-29 & Sequencing platforms & Illumina HiSeq 2000 \\
MIGS-31.2 & Sequencing coverage & Illumina (761×) \\
MIGS-30 & Assemblers & Velvet 1.1.05, phrap SPS-4.24, Allpaths version 39750 \\
& Gene calling methods & Prodigal 1.4, GenePRIMP \\
MIGS-32 & GOLD ID & Gi08842 \\
& NCBI project ID & 89687 \\
& Database: IMG & 2517093000 \\
& Project relevance & Symbiotic $\mathrm{N}_{2}$ fixation, ag riculture \\
\hline
\end{tabular}




\section{Genome sequencing and assembly}

The genome of $R$. l. trifolii strain SRDI943 was sequenced at the Joint Genome Institute (JGI) using an Illumina sequencing platform. An Illumina short-insert paired-end (PE) library with an average insert size of $270 \mathrm{bp}$ produced 18,764,470 reads and an Illumina CLIP long-insert paired-end (PE) library with an average insert size of 9,482 bp produced 18,761,080 reads totaling 5,629 Mb of Illumina data for this genome. All general aspects of library construction and sequencing performed at the JGI can be found at the DOE JGI user homepage [35]. The initial draft assembly contained 5 contigs in 5 scaffolds. The initial draft data was assembled with Allpaths, version 39750. The Allpaths consensus was computationally shredded into $10 \mathrm{~Kb}$ overlapping fake reads (shreds). Illumina sequencing data were assembled with Velvet, version 1.1.05 [36], and the consensus sequences were computationally shredded into $1.5 \mathrm{~kb}$ overlapping fake reads (shreds). The Allpaths consensus shreds, the Illumina VELVET consensus shreds and a sub-set of the Illumina CLIP paired-end reads were integrated using parallel phrap, version SPS - 4.24 (High Performance Software, LLC). The software Consed [37-39] was used in the following finishing process. The estimated genome size is $7.4 \mathrm{Mb}$ and the final assembly is based on $5,629 \mathrm{Mb}$ of Illumina draft data which provides an average of $761 \times$ coverage of the genome.

\section{Genome annotation}

Genes were identified using Prodigal [40] as part of the DOE-JGI annotation pipeline [41] annotation pipeline, followed by a round of manual curation using the JGI GenePRIMP pipeline [42]. The predicted CDSs were translated and used to search the National Center for Biotechnology Information (NCBI) non-redundant database, UniProt, TIGRFam, Pfam, PRIAM, KEGG, COG, and InterPro databases. These data sources were combined to ascribe a product description for each predicted protein. Non-coding genes and miscellaneous features were predicted using tRNAscan-SE [43], RNAMMer [44], Rfam [45], TMHMM [46], and SignalP [47]. Additional gene prediction analyses and functional annotation were performed within the Integrated Microbial Genomes (IMG-ER) platform $[35,48]$.

\section{Genome properties}

The genome is 7,412,387 nucleotides with $60.69 \%$ GC content (Table 4) and comprised of 5 scaffolds (Figure 3) of 5 contigs. From a total of 7,406 genes, 7,317 were protein encoding and 89 RNA only encoding genes. The majority of genes (78.5\%) were assigned a putative function whilst the remaining genes were annotated as hypothetical. The distribution of genes into COGs functional categories is presented in Table 5.

Table 4. Genome Statistics for Rhizobium legum inosarum bv. trifolii SRDI943

\begin{tabular}{lrr}
\hline Attribute & Value & \% of Total \\
\hline Genome size (bp) & $7,412,387$ & 100.00 \\
DNA coding reg ion (bp) & $6,395,342$ & 86.28 \\
DNA G+C content (bp) & $4,498,817$ & 60.69 \\
Number of scaffolds & 5 & \\
Number of contigs & 5 & \\
Total gene & 7,406 & 100.00 \\
RNA genes & 89 & 1.20 \\
rRNA operons & 3 & \\
Protein-coding genes & 7,317 & 98.80 \\
Genes with function prediction & 5,814 & 78.50 \\
Genes assig ned to COGs & 5,770 & 77.91 \\
Genes assigned Pfam domains & 6,032 & 81.45 \\
Genes with signal peptides & 631 & 8.52 \\
Genes with transmembrane proteins & 1,618 & 21.85 \\
CRISPR repeats & 0 & \\
\hline
\end{tabular}


pRL.1
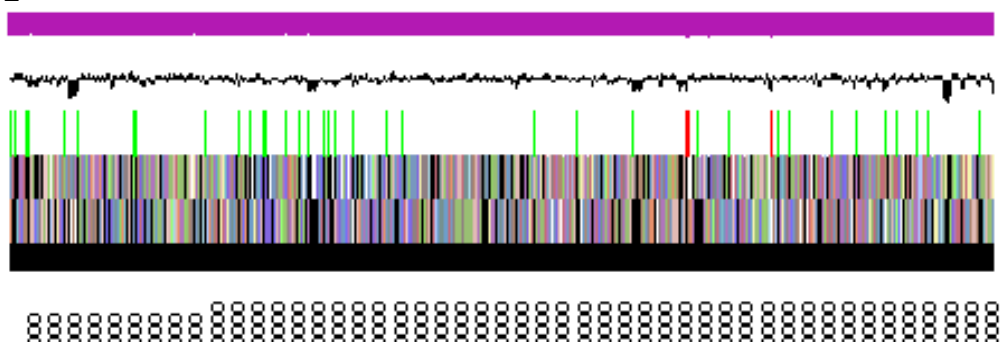

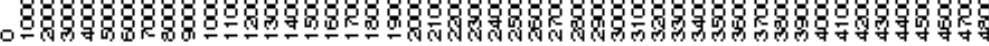
pRL.2

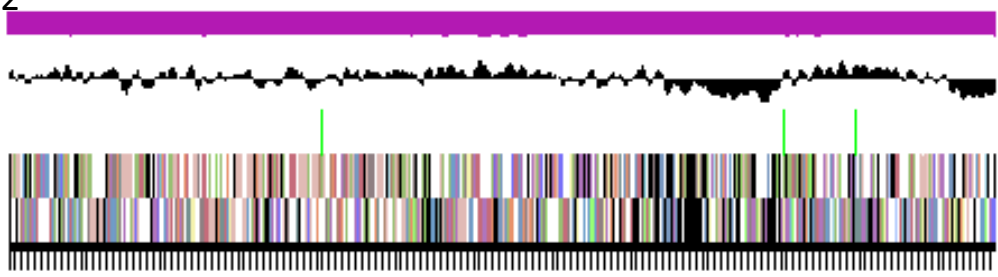

PRL.3

\begin{tabular}{lllllllllllllll}
8 & 8 & 8 & 8 & 8 & 8 & 8 & 8 & 8 & 8 & 8 & 8 & 8 & 8 & 8 \\
\hline & 8 & 8 & 8 & 8 & 8 & 8 & 8 & 8 & 8 & 8 & 8 & 8 & 8 & 8 \\
\hline
\end{tabular}
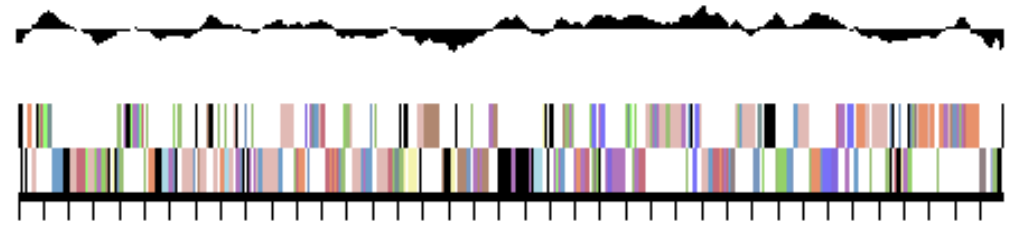

pRL. .4
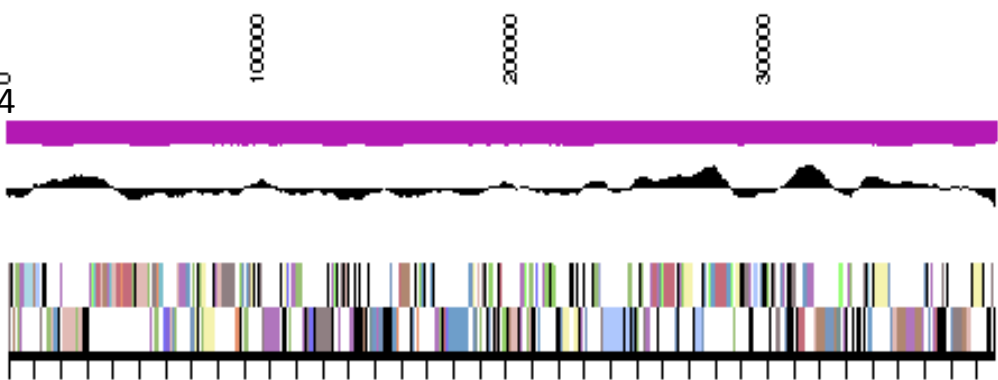

pRL. $5^{\circ}$
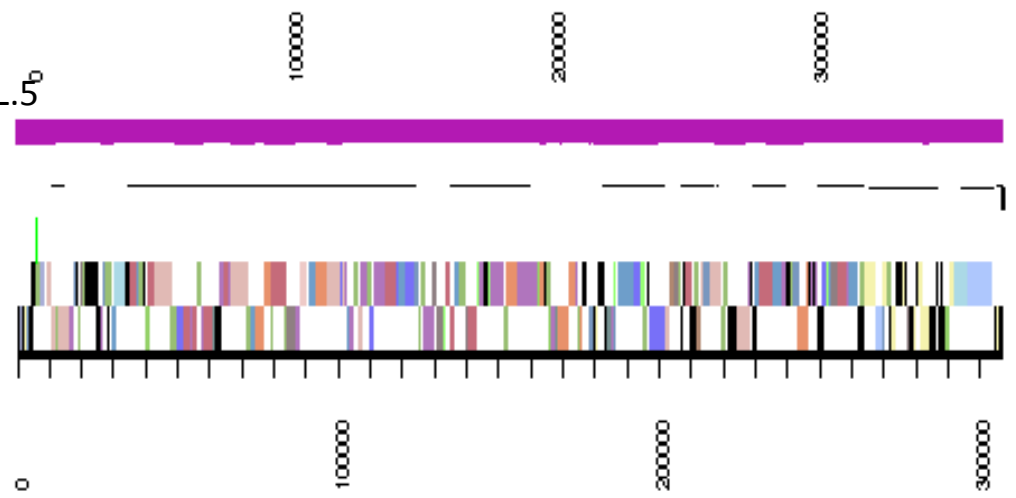

Figure 3. Graphical map of the genome of Rhizobium leguminosarum bv. trifolii strain SRDI943. From bottom to the top of each scaffold: Genes on forward strand (color by COG categories as denoted by the IMG platform), Genes on reverse strand (color by COG categories), RNA genes (tRNAs green, sRNAs red, other RNAs black), GC content, GC skew. 
Table 5. Number of protein coding genes of Rhizobium le gum inosarum bv. trifolii SRDI943 associated with the general COG functional categ ories.

\begin{tabular}{|c|c|c|c|}
\hline Code & Value & \%age & COG Categ ory \\
\hline$J$ & 196 & 3.03 & Translation, ribosomal structure and biogenesis \\
\hline A & 1 & 0.02 & RNA processing and modification \\
\hline K & 652 & 10.06 & Transcription \\
\hline $\mathrm{L}$ & 231 & 3.57 & Replication, recombination and repair \\
\hline B & 2 & 0.03 & Chromatin structure and dynamics \\
\hline $\mathrm{D}$ & 40 & 0.62 & Cell cycle control, mitosis and meiosis \\
\hline $\mathrm{Y}$ & 0 & 0.00 & Nuclear structure \\
\hline V & 76 & 1.17 & Defense mechanisms \\
\hline $\mathrm{T}$ & 373 & 5.76 & Signal transduction mechanisms \\
\hline M & 334 & 5.16 & Cell wall/membrane biog enesis \\
\hline $\mathrm{N}$ & 92 & 1.42 & Cell motility \\
\hline Z & 1 & 0.02 & Cytoskeleton \\
\hline W & 1 & 0.02 & Extracellular structures \\
\hline$U$ & 95 & 1.47 & Intracellular trafficking and secretion \\
\hline $\mathrm{O}$ & 193 & 2.98 & Posttranslational modification, protein turnover, chaperones \\
\hline $\mathrm{C}$ & 324 & 5.00 & Energy production conversion \\
\hline G & 714 & 11.02 & Carbohydrate transport and metabolism \\
\hline $\mathrm{E}$ & 659 & 10.17 & Amino acid transport metabolism \\
\hline $\mathrm{F}$ & 109 & 1.68 & Nucleotide transport and metabolism \\
\hline $\mathrm{H}$ & 192 & 2.96 & Coenzyme transport and metabolism \\
\hline I & 227 & 3.50 & Lipid transport and metabolism \\
\hline$P$ & 333 & 5.14 & Inorganic ion transport and metabolism \\
\hline Q & 165 & 2.55 & Secondary metabolite biosynthesis, transport and catabolism \\
\hline $\mathrm{R}$ & 842 & 13.00 & General function prediction only \\
\hline $\mathrm{S}$ & 627 & 9.68 & Function unknown \\
\hline - & 1,636 & 22.09 & Not in COGS \\
\hline
\end{tabular}




\section{Acknowledgements}

This work was performed under the auspices of the US Department of Energy's Office of Science, Biological and Environmental Research Program, and by the University of California, Lawrence Berkeley National Laboratory under contract No. DE-AC02-05CH11231, Lawrence Livermore National Laboratory under Contract No. DEAC52-07NA27344, and Los Alamos National Laboratory under contract No. DE-AC02-06NA25396. We gratefully acknowledge the funding received from the Mur-

\section{References}

1. O'Hara GW. The role of nitrog en fixation in crop production. J Crop Prod 1998; 1:115-138. http://dx.doi.org/10.1300//144v01n02 06

2. Howieson JG, Yates RJ, Foster K, Real D, Besier B. Prospects for the future use of legumes. In: Dilworth MJ, James EK, Sprent JI, Newton WE, editors. Leguminous Nitrog en-Fixing Symbioses. London, UK: Elsevier; 2008. p 363-394.

3. Herridge DF, Peoples MB, Boddey RM. Global inputs of biological nitrogen fixation in ag ricultural systems. Plant Soil 2008; 311:1-18. http://dx.doi.org/10.1007/s11104-008-9668-3

4. Unkovich MJ, Baldock J, Peoples MB. Prospects and problems of simple linear models for estimating symbiotic $\mathrm{N}_{2}$ fixation by crop and pasture leg umes. Plant Soil 2010; 329:75-89. http://dx.doi.org/10.1007/s11104-009-0136-5

5. Denton MD, Coventry DR, Bellotti WD, Howieson JG. Distribution, abundance and symbiotic effectiveness of Rhizobium leguminosarum bv. trifolii from alkaline pasture soils in South Australia. Anim Prod Sci 2000; 40:25-35. http://dx.doi.org/10.1071/EA99035

6. Drew EA, Charman N, Dingemanse R, Hall E, Ballard RA. Symbiotic performance of Mediterranean Trifolium spp. with naturalised soil rhizobia. Crop Pasture Sci 2011; 62:903-913. http://dx.doi.org/10.1071/CP11047

7. Rys GJ, Bonish PM. Effectiveness of Rhizobium trifolii populations associated with Trifolium species in Taranaki, New Zealand. New Zealand Journal of Experimental Agriculture 1981; 9:329335.

http://dx.doi.org/10.1080/03015521.1981.10425 $\underline{430}$

8. Slattery JF, Coventry DR. Acid-tolerance and symbiotic effectiveness of Rhizobium leguminosarum bv. trifolii isolated from subterranean clover growing in permanent pastures. Soil doch University Strategic Research Fund through the Crop and Plant Research Institute (CaPRI), the Centre for Rhizobium Studies (CRS) at Murdoch University and the GRDC National Rhizobium Program (UMU00032). The authors would like to thank the Australia-China Joint Research Centre for Wheat Improvement (ACCWI) and SuperSeed Technologies (SST) for financially supporting Mohamed Ninawi's PhD project.

Biol Biochem 1995; 27:111-115. http://dx.doi.org/10.1016/0038-0717(94)00143-O

9. Drew EA, Ballard RA. Improving $\mathrm{N}_{2}$ fixation from the plant down: Compatibility of Trifolium subterraneum L. cultivars with soil rhizobia can influence symbiotic performance. Plant Soil 2010; 327:261-277. http://dx.doi.org/10.1007/s11104$\underline{009-0052-8}$

10. Sitepu SP. Selection of Balansa clover lines using naturalised soil rhizobia: University of Adelaide; 2001. 96 p.

11. Melino VJ, Drew EA, Ballard RA, Reeve WG, Thom son G, White RG, O'Hara GW. Identifying abnormalities in symbiotic development between Trifolium spp. and Rhizobium leguminosarum bv. trifolii leading to sub-optimal and ineffective nodule phenotypes. Ann Bot (Lond) 2012; 110:15591572. PubMed http://dx.doi.org/10.1093/aob/mcs206

12. Howieson JG, Ewing MA, D'antuono MF. Selection for acid tolerance in Rhizobium meliloti.

Plant Soil 1988; 105:179-188. http://dx.doi.org/10.1007/BF02 376781

13. Field D, Garrity G, Gray T, Morrison N, Seleng ut J, Sterk P, Tatusova T, Thomson N, Allen M, Angiuoli SV, et al. Towards a richer description of our complete collection of genomes and metagenomes "Minimum Information about a Genome Sequence " (MIGS) specification. Nat Biotechnol 2008; 26:541-547. PubMed http://dx.doi.org/10.1038/nbt1360

14. Woese CR, Kandler O, Wheelis ML. Towards a natural system of organisms: proposal for the domains Archaea, Bacteria, and Eucarya. Proc Natl Acad Sci USA 1990; 87:457 6-4579. PubMed http://dx.doi.org/10.1073/pnas.87.12.4576

15. Garrity GM, Bell JA, Lilburn T. Phylum XIV. Proteobacteria phyl. nov. In: Garrity GM, Brenner DJ, Krieg NR, Staley JT (eds), Bergey's Manual of 
Systematic Bacteriology, Second Edition, Volume 2, Part B, Springer, New York, 2005, p. 1.

16. Garrity GM, Bell JA, Lilburn T. Class I. Alphaproteobacteria class. nov. In: Garrity GM, Brenner DJ, Krieg NR, Staley JT (eds), Bergey's Manual of Systematic Bacteriology, Second Edition, Volume 2, Part C, Springer, New York, 2005, p. 1.

17. Validation List No. 107. List of new names and new combinations previously effectively, but not validly, published. Int I Syst Evol Microbiol 2006; 56:1-6. PubMed http://dx.doi.org/10.1099/ijs.0.64188-0

18. Kuykendall LD. Order VI. Rhizobiales ord. nov. In: Garrity GM, Brenner DJ, Kreig NR, Staley JT, editors. Bergey's Manual of Systematic Bacteriology. Second ed: New York: Spring er - Verlag; 2005. p 324.

19. Kuykendall LD. Family I. Rhizobiaceae In: Garrity GM, Brenner DJ, Krieg NR, Staley JT, editors.

Bergey's Manual of Systematic Bacteriology. New York: Spring er - Verlag; 2005.

20. Conn HJ. Taxonomic relationships of certain nonsporeforming rods in soil. / Bacterio/ 1938; 36: $320-321$.

21. Skerman VBD, McGowan V, Sneath PHA. Approved Lists of Bacterial Names. Int J Syst Bacteriol 1980; 30:225-420. http://dx.doi.org/10.1099/00207713-30-1-225

22. Kuykendall LD, Young JM, Martínez-Romero E, Kerr A, Sawada H. Genus I. Rhizobium. In: Garrity GM, Brenner DJ, Krieg NR, Staley JT, editors. Bergey's Manual of Systematic Bacteriology. Second ed. Volume 2. New York: Springer Verlag; 2005.

23. Frank B. Über die Pilzsymbiose der Leg uminosen. Ber Dtsch Bot Ges 1889; 7:332-346.

24. Jordan DC, Allen ON. Genus I. Rhizobium Frank 1889, 338; Nom. gen. cons. Opin. 34, Jud.

Comm. 1970, 11. In: Buchanan RE, Gibbons NE (eds), Bergey's Manual of Determinative Bacteriology, Eighth Edition, The Williams and Wilkins Co., Baltimore, 1974, p. 262-264.

25. Young JM, Kuykendall LD, Martínez-Romero E, Kerr A, Sawada H. A revision of Rhizobium Frank 1889, with an emended description of the genus, and the inclusion of all species of Agrobacterium Conn 1942 and Allorhizobium undicola de Lajudie et al. 1998 as new combinations: Rhizobium radiobacter, $R$. rhizogenes, $R$. rubi, $R$. undic ola and R. vitis. Int / Syst Evol Microbiol 2001; 51:89-103. PubMed

26. Editorial Secretary (for the Judicial Commission of the International Committee on Nomenclature of Bacteria)

27. Ramírez-Bahena $M H$, García-Fraile $P$, Peix A, Valverde A, Rivas R, Igual JM, Mateos PF, Martínez-Molina E, Velázquez E. Revision of the taxonomic status of the species Rhizobium legum inosarum (Frank 1879) Frank 1889AL, Rhizobium phaseoli Dangeard 1926AL and Rhizobium trifolii Dangeard 1926AL. R. trifolii is a later synonym of $R$. leguminosarum. Reclassification of the strain $R$. leguminosarum DSM 30132 (=NCIMB 11478) as Rhizobium pisisp. nov. Int J Syst Evol Microbiol 2008; 58:2484-2490. PubMed http://dx.doi.org/10.1099/ijs.0.65621-0

28. Editorial Secretary (for the Judicial Commission of the International Committee on Nomenclature of Bacteria). OPINION 34: Conservation of the Generic Name Rhizobium Frank 1889. Int J Syst Bacteriol 1970; 20:11-12. http://dx.doi.org/10.1099/00207713-20-1-11

29. Agents B. Technical rules for biological agents. TRBA (http://www.baua.de):466.

30. Ashburner M, Ball CA, Blake JA, Botstein D, Butler $\mathrm{H}$, Cherry JM, Davis AP, Dolinski K, Dwight SS, Eppig JT, et al. Gene ontology: tool for the unification of biology. The Gene Ontology Consortium. Nat Genet 2000; 25:25-29. PubMed http://dx.doi.org/10.1038/75556

31. Tamura K, Peterson D, Peterson N, Stecher G, Nei M, Kumar S. MEGA5: Molecular Evolutionary Genetics Analysis using Maximum Likelihood, Evolutionary Distance, and Maximum Parsimony Methods. Mol Biol Evol 2011; 28:2731-2739. PubMed http://dx.doi.org/10.1093/molbev/msr121

32. Felsenstein J. Confidence limits on phylog enies: an approach using the bootstrap. Evolution 1985; 39:783-791. http://dx.doi.org/10.2307/2408678

33. Liolios K, Mavromatis K, Tavernarakis N, Kyrpides NC. The Genomes On Line Database (GOLD) in 2007: status of genomic and metag enomic projects and their associated metadata. Nucleic Acids Res 2008; 36:D475-D479. PubMed http://dx.doi.org/10.1093/nar/gkm884

34. Reeve WG, Tiwari RP, Worsley PS, Dilworth MJ, Glenn AR, Howieson JG. Constructs for insertional mutagenesis, transcriptional signal localization and gene regulation studies in root nodule and other bacteria. Microbiology 1999; 
145:1307-1316. PubMed

http://dx.doi.org/10.1099/13500872-145-6-1307

35. DOE Joint Genome Institute. http://my.jgi.doe.g ov/g eneral/index.html

36. Zerbino DR. Using the Velvet de novo assembler for short-read sequencing technolog ies. Current Protocols in Bioinformatics 2010; Chapter 11:Unit 115.

37. Ewing B, Green P. Base-calling of automated sequencer traces using phred. II. Error probabilities. Genome Res 1998; 8:186-194. PubMed http://dx.doi.org/10.1101/gr.8.3.175

38. Ewing B, Hillier L, Wendl MC, Green P. Basecalling of automated sequencer traces using phred. I. Accuracy assessment. Genome Res 1998; 8:175-185. PubMed http://dx.doi.org/10.1101/g r.8.3.175

39. Gordon D, Abajian C, Green P. Consed: a graphical tool for sequence finishing. Genome Res 1998; 8:195-202. PubMed http://dx.doi.org/10.1101/gr.8.3.195

40. Hyatt $\mathrm{D}$, Chen $\mathrm{GL}$, Locascio PF, Land ML, Larimer FW, Hauser LJ. Prodig al: prokaryotic gene recognition and translation initiation site identification. BMC Bioinformatics 2010; 11:119. PubMed http://dx.doi.org/10.1186/1471-2105-11-119

41. Mavromatis K, Ivanova NN, Chen IM, Szeto E, Markowitz VM, Kyrpides NC. The DOE-JGl Standard operating procedure for the annotations of microbial genomes. Stand Genomic Sci 2009; 1:63-67. PubMed http://dx.doi.org/10.4056/sig s.632

42. Pati A, Ivanova NN, Mikhailova N, Ovchinnikova G, Hooper SD, Lykidis A, Kypides NC.
GenePRIMP: a gene prediction improvement pipeline for prokaryotic genomes. Nat Methods 2010; 7:455-457. PubMed http://dx.doi.org/10.1038/nmeth.1457

43. Lowe TM, Eddy SR. tRNAscan-SE: a prog ram for improved detection of transfer RNA genes in genomic sequence. Nucleic Acids Res 1997; 25:955-964. PubMed

44. Lagesen K, Hallin P, Rodland EA, Staerfeldt HH, Rog nes T, Ussery DW. RNAmmer: consistent and rapid annotation of ribosomal RNA genes. Nucleic Acids Res 2007; 35:31 00-3108. PubMed http://dx.doi.org/10.1093/nar/g km160

45. Griffiths-Jones S, Bateman A, Marshall M, Khanna A, Eddy SR. Rfam: an RNA family database. $\mathrm{Nu}$ cleic Acids Res 2003; 31:439-441. PubMed http://dx.doi.org/10.1093/nar/g kg 006

46. Krogh A, Larsson B, von Heijne G, Sonnhammer EL. Predicting transmembrane protein topology with a hidden Markov model: application to complete genomes. / Mol Biol 2001; 305:567580. PubMed http://dx.doi.org/10.1006/jmbi.2000.4315

47. Bendtsen JD, Nielsen H, von Heijne G, Brunak S. Improved prediction of sig nal peptides: SignalP 3. 0. J Mol Biol 2004; 340:783-795. PubMed http://dx.doi.org/10.1016/j.jmb.2004.05.028

48. Markowitz VM, Mavromatis K, Ivanova NN, Chen IM, Chu K, Kyrpides NC. IMG ER: a system for microbial genome annotation expert review and curation. Bioinformatics 2009; 25:2271-2278. PubMed http://dx.doi.org/10.1093/bioinformatics/btp393 